\title{
PENGARUH KONFIGURASI POLITIK HUKUM ORDE BARU TERHADAP KOMPILASI HUKUM ISLAM (KHI) DI INDONESIA
}

\author{
Mochammad Muslim \\ Universitas Islam Negeri Sunan Ampel Surabaya | judulsj@gmail.com
}

\begin{abstract}
This article discusses the influence of legal political configuration of the New Order against the Compilation of Islamic Law in Indonesia. Legal political configuration of the New Order was based on Pancasila and the Constitution of 1945 as the basis of its policy to enhance and improve national law. The background formation of $\mathrm{KHI}$ is the need for technical justicial Religious Courts. $\mathrm{KHI}$ can be regarded as Indonesian fiqh sound Pancasila due to the influence of political codification and unification of the law of the New Order. This study efforts to prove that the relationship between the political configuration and character of legal product that produces any legal products is a reflection of the political configuration that gave it birth. The character of the law product is determined by the political vision that developed in the midst of society. Sometimes the character of legal product is responsive/populistic and there is also a legal product was characterized by conservative/orthodox/elitist. Likewise with $\mathrm{KHI}$ must have certain characters were born as a result of legal political configuration of the New Order regime.
\end{abstract}

Keywords: Effect, political configuration, the new order, and $\mathrm{KHI}$

\begin{abstract}
Abstrak: Artikel ini membahas tentang pengaruh konfigurasi politik hukum Orde Baru terhadap Kompilasi Hukum Islam di Indonesia. Konfigurasi politik hukum Orde Baru itu berlandaskan Pancasila dan UUD 1945 sebagai dasar kebijakannya untuk meningkatkan dan menyempurnakan hukum nasional. Yang menjadi latar belakang terbentuknya $\mathrm{KHI}$ adalah adanya kebutuhan teknis yustisial Peradilan Agama. KHI dapat dikatakan sebagai fiqh Indonesia yang berwawasan Pancasila akibat pengaruh dari politik kodifikasi dan unifikasi hukum Orde Baru. Studi ini berupaya membuktikan bahwa hubungan antara konfigurasi politik dan karakter produk hukum menghasilkan bahwa setiap produk hukum merupakan pencerminan dari konfigurasi politik
\end{abstract}


yang melahirkannya. Karakter produk hukum sangat ditentukan oleh visi politik yang berkembang di tengah-tengah masyarakat. Adakalanya produk hukum itu berkarakter responsif/populistik dan ada juga produk hukum itu berkarakter konservatif/ortodoks/elitis. Begitu juga dengan $\mathrm{KHI}$ pasti mempunyai karakter-karakter tertentu akibat dilahirkan dari konfigurasi politik hukum rezim Orde Baru.

Kata Kunci: Pengaruh, konvigurasi politik, orde baru, dan KHI

\section{Pendahuluan}

Indonesia dalam peta dunia merupakan fenomena keislaman tersendiri, baik dari aspek kenegaraan maupun pluralitas masyarakatnya. Indonesia mempunyai spesifikasi yang membedakan dengan negara-negara muslim lainnya. Para pemerhati dunia Islam merasa belum lengkap jika tidak menyertakan Indonesia dalam kajiannya. Banyak hal yang membuat Indonesia diperhitungkan sebagai obyek kajian Islam dan masyarakat muslim di tingkat dunia. Selain karena berpenduduk muslim terbesar di dunia, juga di tengah-tengah kehidupan mayoritas muslim ini, segala persoalan kenegaraan, kebangsaan dan kemasyarakatannya tidak didasarkan pada suatu paham keagamaan. Justru, yang dijadikan pandangan hidup (way of life) dan ideologi negara adalah Pancasila, yakni sejumlah nilai dasar yang digali dari bumi Indonesia sendiri.

Hukum Islam sebagai tatanan hukum yang dipegangi (ditaati) oleh mayoritas umat Islam di Indonesia adalah hukum yang telah lama hidup di dalam masyarakat, merupakan sebagian dari ajaran dan keyakinan umat Islam dan ada dalam hukum nasional serta merupakan bahan dalam pembinaan dan pengembangannya. Dari sumber ajarannya, realitas kehidupan hukum masyarakat, sejarah pertumbuhannya dan perkembangan hukum di Indonesia, yang menyangkut teori berlakunya hukum Islam di Indonesia. Terlihat ada beberapa teori yang sudah ada dalam pertumbuhan. Di antaranya teori receptie yang dikembangkan oleh Belanda yang ingin menjauhkan masyarakat Islam dari hukum Islam demi memantapkan penjajahannya di 
Indonesia. ${ }^{1}$ Setelah Indonesia merdeka, berlaku UUD 1945 dan Pancasila menjadi dasar falsafah negara, timbul keinginan dan semangat merdeka dalam hukum. Maka muncullah teori receptie exit dan teori receptia a contrario. ${ }^{2}$

Dalam suatu negara hukum yang berdasarkan pancasila ini, masyarakat muslim Indonesia mengamalkan (sebagian) hukum agamanya (Syari'ah). Tentu saja secara simplistic dapat diduga bahwa sepanjang sejarahnya, perjuangan menegakkan hukum Islam di wilayah negara Pancasila senantiasa mengalami masamasa ketegangan dan bargaining of power dengan kekuasaan negara, sebagai pola artikulasi relasi keduanya. Dealektika hukum Islam dengan politik negara terjadi terus-menerus. Pada tataran ini, politik hukum suatu negara harus diakui berperan dalam menentukan kebijakan pemberlakuan hukum, apalagi hukum Islam.

Islam yang masuk ke Indonesia tampaknya mempunyai tipologi tersendiri. Selain sudah menjadi bagian dari firqoh fikriyah (faksi pemikiran) yang ada dalam sejarah hukum Islam, juga keberadaannya banyak dipengaruhi oleh tradisi dan kebudayaan asli Indonesia. Animisme dan Dinamisme tercatat banyak mewarnai proses pembentukan model dan definisi Islam ala Indonesia.

Melekat dalam tipologi khas adalah realitas masyarakat Indonesia yang berwajah plural. Beraneka ragam suku, agama, ras dan golongan merupakan unsur dasar struktur masyarakat Indonesia. Lebih menarik lagi kendati agama merupakan unsur dominan di dalam masyarakat, tetapi Indonesia sebagai negara tidak didasarkan pada suatu agama atau paham dari agama tertentu. Upaya menjadikan agama sebagai dasar negara dalam pembentukan nation state selalu mengalami kegagalan. Bahkan

\footnotetext{
I Ichtijanto, "Pengembangan Teori Berlakunya Hukum Islam di Indonesia," dalam Juhaya S. Praja (ed.), Hukum Islam di Indonesia: Perkembangan dan Pembentukannya, Cet. I, (Bandung: Remaja Rosdakarya, 1991), 100 ${ }^{2} \mathrm{lbid}$.
} 
dalam perkembangannya, dasar negara ini kemudian ditetapkan sebagai satu-satunya ideologi eksklusif yang boleh hidup dan harus diterima di wilayah nusantara ini lewat gaya otoritarianisme korporatis. ${ }^{3}$

Jika dilihat dari perkembangan hukum Islam di Indonesia terciptanya tiga persimpangan jalan. Suatu jalan menuju pemberlakuan hukum Islam berasal dari kelompok yang menghendaki hukum Islam dapat berlaku di Indonesia untuk mengatur pemeluknya. Satu jalan dari kelompok penguasa yang menginginkan adanya kesatuan dan keseragaman hukum. Kelompok ini didukung oleh para sarjana hukum Barat, khususnya Belanda. Simpang jalan ketiga adalah kelompok yang menginginkan tidak berlakunya hukum Islam secara melembaga. Golongan ini yang senantiasa mencekal dan mengemukakan bahwa setiap ide pengembangan hukum Islam mencekal, dengan alasan klasik, berarti menginginkan mendirikan negara Islam atau pemberlakuan kembali piagam Jakarta.

Kecurigaan politik terhadap umat Islam merupakan kelanjutan dari adanya gesekan-gesekan ideologis. Bahkan kecurigaan itu berkembang menjadi antagonisme politik yang semakin menyudutkan posisi umat Islam. Lebih parah lagi baik kecurigaan maupun antagonisme itu tumbuh di kedua belah pihak (Islam dan negara). ${ }^{4}$

Dalam hubungan yang antagonistik tersebut, baik penerapan maupun penyerapan kaidah-kaidah hukum Islam ke dalam hukum nasional menjadi agak terhalang, begitu juga sebaliknya ide dan program penguasa dalam menjalankan pembangunan, secara tidak langsung menjadi terpengaruh. Sebab kedua pihak mempunyai kekuatan dan berpengaruh di tengah-tengah

${ }^{3}$ Marzuki Wahid, "Konfigurasi Politik Hukum Islam di Indonesia: Studi tentang Pengaruh Politik Orde Baru terhadap Kompilasi Hukum Islam", dalam Mimbar Studi, Nomor 2 Tahun XXII, Januari-April, 1999, I0 I

${ }^{4}$ Abdul Halim, Peradilan Agama Dalam Politik Hukum di Indonesia: dari Otoriter Konservatif Menuju Konfigurasi Demokratis-Responsif, (Jakarta: PT. RajaGrafindo Persada, 2000), 3 
masyarakat. Jalan keluarnya adalah menciptakan hubungan saling pengertian antara apa yang menjadi cita-cita penguasa atau pemerintah dengan ide dan cita-cita pihak Islam. Kesepahaman ini dengan sendirinya akan melahirkan hubungan yang harmonis, karena hubungan tersebut didasari oleh cita-cita hukum bukan cita-cita politik an sich. Oleh sebab itu yang perlu diciptakan adalah hubungan yang bersifat akomodatif.

Berdasarkan alasan-alasan tersebut barangkali penerapan dan pemberlakuan hukum Islam secara murni dalam pentas sosial politik Indonesia selalu mengundang polemik. Polemik itu tidak sekedar berkutat pada perkara teknis yuridis belaka, melainkan telah menyentuh pada asas politik yang peka. Demi menjaga komitmen pluralitas, wilayah pemberlakuan hukum Islam direduksi sampai pada tingkat yang membuat penganut agama lain merasa tidak terancam. Posisi hukum Islam disejajarkan dengan hukum barat dan hukum adat, sebagai sub sistem dan sumber inspirasi bagi pembangunan hukum nasional.

Pada saat yang sama, keberadaan negara Orde Baru menurut para pengamat dan pengkaji politik Indonesia muncul sebagai suatu rezim politik yang juga spesifik, yang membedakan dirinya dengan rezim politik sebelumnya. Pada awal perjalanannya, pemerintah Orde Baru menunjukkan langgam libertarian yang sesungguhnya ialah langgam transisi sambil mencari fomat baru bagi konfiguransi politik. Konfiguransi poltik Orde Baru yang menitikberatkan pada pembangunan terutama bidang ekonomi harus diamankan dengan "stabilitas nasional" yang dianggap sebagai pra syarat yang realisasinya ternyata menuntut langgam otoritarian. ${ }^{5}$ Di samping tekatnya yang hendak menjalankan Pancasila dan UUD 1945 secara murni dan konsekuen, juga ciri lain yang signifikan adalah munculnya sosok negara sebagai aktor dominan dalam menentukan pengelolaan sosial, ekonomi dan hukum.

${ }^{5}$ Moh. Mahfud MD, Politik Hukum di Indonesia, (Jakarta: PT. Raja Grafindo Persada, 2009), 196 
Pluralisme agama dan kultur bangsa Indonesia dalam upaya pembentukan dan pembinaan hukum nasional, terjadi tarik menarik antara satu kepentingan dengan kepentingan lain. Dalam keadaan seperti ini cengkeraman politik terhadap hukum tidak terelakkan. Indikasi ini ditemui pada proses pelaksanaan hukum, di mana pihak-pihak yang berkepentingan berusaha mempengaruhi pelaksanaan kebijakan yang sudah berbentuk hukum, sejalan dengan kepentingan kekuatan serta searah dengan faktor masa dan ruang yang mengelilinginya. ${ }^{6}$

Berkenaan dengan rezim Orde Baru ini maka pemberlakuan dan penerapan hukum Islam dikemudikan oleh negara sesuai dengan kehendak politiknya. Partisipasi masyarakat luas kurang mendapatkan tempat yang cukup berarti di bidang pembinaan hukum. Hal ini berarti bahwa politik hukum Orde Baru untuk sebagian besar merefleksikan cara pemerintah memandang persoalan sosial yang dihadapi oleh masyarakat Indonesia. ${ }^{7} \mathrm{Di}$ Indonesia, pembinaan hukum nasional dilakukan dengan menggunakan sumber-sumber yang ada di negara ini, dalam situasi terrtentu digunakan pula bahan yang berasal dari manca negara. Sumber-sumber yang berasal dari kebudayaan hukum Indonesia, pada dasarnya, terdiri dari hukum Barat, hukum adat yang beraneka ragam, hukum Islam dan hukum agama lain yang tetap mengacu kepada kepentingan nasional dan dapat diterima oleh semua pihak. ${ }^{8}$

Jika diperhatikan konfigurasi pemikiran pemerintah Orde Baru dalam aspek pembangunan hukum nasional, maka rezim ini cenderung memilih format hukum dengan mengembangkan konsep kesatuan hukum dalam pembinaan hukum nasional, di mana hukum agama yang dianut mayoritas masyarakat tidak serta

\footnotetext{
${ }^{6}$ Arbi Sanit, Swadaya Politik Masyarakat: Telaah Tentang Keterikatan Organisasi Masyarakat: Partisipasi Politik Pertumbuhan Hukum Dan Hak Asasi, (Jakarta: Rajawali Press, 1985), 84

${ }^{7}$ A. DJazuli, "Beberapa Aspek Pengembangan Hukum Islam", dalam Juhaya S. Praja. Hukum Islam di Indonesia: Pemikiran dan Praktek, (Bandung: Remaka Rosdakarya, 1994), 234

${ }^{8}$ Ibid., 235
} 
merta dapat dijadikan sebagai hukum yang berlaku. Beberapa hukum agama untuk diangkat menjadi materi hukum membutuhkan kerja keras dari umat Islam, meskipun sebenarnya hukum itu diberlakukan hanya untuk pemeluk agama tersebut. Hukum agama dalam persepsi pemerintah Orde Baru bukan sebagai hukum sebagai the living law yang secara konsep ilmu hukum mesti diterapkan, tetapi lebih melihatnya sebagai ajaran yang tidak mengakar ke bumi, oleh sebab itu hanya untuk dipahami bukan untuk dilaksanakan. Pandangan seperti ini jelas memberikan pengaruh bagi eksistensi hukum Islam.

Argumentasi yang digunakan rezim Orde Baru ingin menciptakan suatu sistem yang mana kehidupan ekonomi, politik dan budaya dapat diterima semua pihak yakni didasarkan pada Pancasila dan UUD 1945.9 Semua yang berada di luar wawasan kesatuan ini harus berhadapan dengan pemerintah atau malah disingkirkan dan dihilangkan dari wacana pemikiran maupun gerakan. Yang menjadi target dalam tataran pemikiran ini adalah konsep "kesamaan" meski terkadang kelompok agama mayoritas harus turut dengan kelompok agama minoritas. Yang dikehendaki hanya pokoknya sama, meski kelihatan kurang proporsional.

Namun kemudian kecenderungan terhadap penciptaan kesatuan hukum atas dasar pluralisme dan heterogenitas masyarakat dan tatanan hukum (hukum Islam, Adat dan Barat), maka yang muncul dan malah tidak terelakkan perseteruan dan pergumulan antara satu kepentingan politik (negara) dengan umat Islam yang pro terhadap keberadaan hukum Islam. Antara kubu pro hukum sipil dengan kubu hukum adat dan hukum Islam, antara elit agama dengan political power.

Negara memegang hak monopoli atas pemberlakuan hukum di tengah-tengah kehidupan masyarakat. Justifikasi kekuasaan negara dengan demikian menjadi kunci bagi keabsahan hukum. Legislasi hukum Islam menjadi suatu keharusan formal yuridis,

\footnotetext{
${ }^{9}$ Abdul Halim, Peradilan Agama, 5
} 
yang sekaligus turut menentukan eksistensinya di bumi nusantara ini. Dalam keharusan legislasi itu, keberadaan Kompilasi Hukum Islam (KHI) harus mendapat instrumentasi hukum positif, walaupun dalam bentuk inpres. Kedudukan hukum Islam dalam tata negara Orde Baru dua dekade terakhir tidak hanya telah dijadikan sumber hukum yang telah mempunyai kekuatan hukum, akan tetapi keberadaannya telah diakui secara utuh, bahkan sebagian telah dibuktikan lewat legislasi.

KHI dapat dikatakan sebagai prestasi puncak umat Islam Indonesia dalam menjadikan sebagian substansi hukum Islam (ahwal al syakhsiyah, the family law) sebagai hukum positif dewasa ini. KHI dibentuk oleh Departemen Agama RI, Mahkamah Agung RI dan Majelis Ulama Indonesia, dan tokoh masyarakat Islam.

Visi politik negara memang mempunyai peluang besar untuk menentukan arah politik hukum yang akan dilahirkannya, baik secara teoritis maupun dalam tataran realitas historis, karena studi ini berangkat dari asumsi dasar bahwa hukum merupakan produk politik yang memandang hukum sebagai formalisasi atau kristalisasi dari kehendak-kehendak politik yang saling berinteraksi. Bahkan menurut Daniel S. Lev, sebagaimana dikutip Moh. Mahfud, bahwa dalam hubungan tolak tarik antara politik dan hukum, maka hukumlah yang terpengaruh oleh politik, karena sub sistem politik memiliki konsentrasi energi yang lebih besar daripada hukum. Sehingga jika harus berhadapan dengan politik, maka hukum berada dalam kedudukan yang lebih lemah. ${ }^{10}$ Karena lebih kuatnya konsentrasi energi politik, maka menjadi alasan adanya konstalasi bahwa kerap kali otonomi hukum di Indonesia ini diintervensi oleh politik, bukan hanya dalam proses pembuatannya, tetapi juga dalam implementasinya. ${ }^{11}$

Prinsip yang menyatakan bahwa politik dan hukum harus bekerjasama dan saling menguatkan melalui ungkapan "hukum tanpa kekuasaan adalah angan-angan, kekuasaan tanpa hukum

\footnotetext{
${ }^{10}$ Moh. Mahfud MD, Politik Hukum, 13

"Ibid.
} 
adalah kelaliman", menjadi semacam utopi belaka. Hal itu terjadi karena di dalam prakteknya hukum kerap kali menjadi cermin dari kehendak pemegang kekuasaan politik sehingga tidak sedikit orang yang memandang bahwa hukum sama dengan kekuasaan. ${ }^{12}$

Dengan pernyataan hipotesis yang lebih spesifik dapat dikemukakan bahwa konfigurasi politik suatu negara akan melahirkan produk hukum tertentu di negara tersebut. Di dalam negara yang konfigurasi politiknya demokratis, maka produk hukumnya berkarakter responsif/populistik, sedangkan di negara yang konfigurasi politiknya otoriter, maka produk hukumnya berkarakter ortodok/konservatif/elitis. Perubahan konfigurasi politik dari otoriter ke demokratis atau sebaliknya berimplikasi pada perubahan karakter produk hukum.

Berkenaan dengan uraian di atas, bagi penulis melahirkan asumsi bahwa KHI merupakan produk hukum Islam yang mempunyai karakter dan visi politik sendiri, karena berada dalam kungkungan kooptasi politik hukum Orde Baru.

\section{Pengertian Kompilasi Hukum Islam}

Kompilasi menurut bahasa ialah karangan (buku) yang tersusun dari kutipan-kutipan buku-buku lain. ${ }^{13}$ Apabila dikaitkan dengan hukum, maka kompilasi dapat diartikan sebagai himpunan materi hukum dalam suatu buku. Kompilasi Hukum Islam yang selanjutnya disingkat dengan KHI ditetapkan pada tahun 1991 secara tegas tidak menyebutkan bagaimana pengertian Kompilasi Hukum Islam (KHI).

Menurut Abdul Ghani Abdullah, KHI adalah rumusan tertulis dari hukum Islam yang hidup dalam masyarakat di tengah kondisi hukum dan masyarakat Indonesia. ${ }^{14}$ Sedangkan menurut Ahmad Azhar Basyir, KHI merupakan hasil proyek pembangunan

\footnotetext{
${ }^{12}$ Ibid., 12

13 Pius A. Partanto, M. Dahlan Al-Barry, Kamus I/miyah Populer, (Surabaya: Arkola, 1994), 353

${ }^{14}$ Abdul Gani Abdullah, "Pemasyarakatan Inpres No. I/I99| Tentang Kompilasi Hukum Islam", dalam Mimbar Hukum, No. 5 Thn. III, 1992, II9
} 
hukum Islam melalui yurisprudensi yang dilaksanakan oleh Mahkamah Agung RI dan Departemen Agama RI, kekuatan hukum diperoleh dengan inpres No. 1 Tahun 1991. ${ }^{15}$

Kompilasi Hukum Islam (KHI) jika dilihat dari sejarah penyusunannya dapat diambil kesimpulan bahwa yang dimaksud KHI adalah himpunan kaidah-kaidah hukum Islam yang ditulis dan disusun secara teratur dan sistematis, diambil dari berbagai kitab (pendapat para fuqaha/doktrin) yang dipergunakan sebagai referensi pada Pengadilan Agama.

\section{Latar Belakang Penyusunan KHI}

Kemunculan penyusunan KHI dilatarbelakangi dan didorong oleh kebutuhan teknis yustisial Peradilan Agama. Kebutuhan ini dirasakan oleh Mahkamah Agung selaku pembina teknis yustisial, sejak tahun 1983, saat dimulai pelaksanaan UU Nomor 14 Tahun 1970 tentang ketentuan-ketentuan pokok kekuasaan kehakiman dalam lingkungan Peradilan Agama. Kebutuhan yang dimaksud adalah tiadanya satu buku hukum yang menghimpun semua hukum terapan yang berlaku bagi lingkungan Peradilan Agama yang dapat dijadikan pedoman oleh para hakim dalam melaksanakan tugasnya, sehingga terjamin adanya kesatuan dan kepastian hukum. ${ }^{16}$

Di sisi lain penyusunan KHI (sebagai noma hukum yang akan diterapkan di Indonesia) ada kaitannya dengan pemenuhan komulasi dimensi horisontal dan transcendental. Sebab pada akhirnya hukum itu hanya mungkin berlaku efektif dalam masyarakat, terutama penerapan dimensi horisontalnya, apabila hukum mempunyai nilai-nilai kebenaran yang diyakini masyarakat tempat hukum itu diberlakukan.

${ }^{15}$ Ahmad Azhar Basyir, "Pemasyarakatan Kompilasi Hukum Islam Melalui Jalur Pendidikan Non Formal" dalam Mimbar Hukum, No. 5 Tahun III 1992, 105

${ }^{16}$ Saekan, dan Erniati Effendi, Sejarah Penyusunan Kompilasi Hukum Islam di Indonesia, cet. ke-I, (Surabaya: Arkola, 1997), 4 


\section{Tujuan Penyusunan KHI}

Tujuan utama KHI adalah "mempositifkan" hukum Islam di Indonesia. Dengan mempositifkan hukum Islam secara terumus dan sistematik dalam "kitab hukum", terdapat beberapa sasaran pokok yang hendak dicapai dan dituju:

1) Melengkapi pilar peradilan agama

2) Menyamakan persepsi penerapan hukum

3) Menyingkirkan paham private affair

4) Mempercepat proses Taqribi Bainal Ummah

\section{Karakter Produk Hukum Masa Orde Baru}

Dalam menentukan karakter produk hukum masa Orde Baru, yang dijadikan sebagai studi kasus pada kajian ini meminjam teori yang digunakan oleh Mahfud MD. ${ }^{17}$ Ada dua karakter produk hukum :

1. Produk hukum responsive atau populistik

Produk hukum responsive atau populistik adalah produk hukum yang mencerminkan rasa keadilan dan memenuhi harapan masyarakat. Dalam proses pembuatannya memberikan peranan besar dan partisipasinya penuh kelompok-kelompok sosial atau individu di dalam masyarakat. Hasilnya bersifat responsive terhadap tuntutan-tuntutan kelompok sosial atau individu dalam masyarakat.

2. Produk hukum konservatif/ortodok/elitis

Produk hukum yang isinya lebih mencerminkan visi sosial elit politik, lebih mencerminkan keinginan pemerintah, bersifat positif instrumentalis, yakni menjadi alat pelaksana ideology dan program negara. Berlawanan dengan hukum responsive, hukum ortodoks lebih tertutup terhadap tuntutan-tuntutan kelompok maupun individu-individu dalam masyarakat. Dalam pembuatannya peranan dan partisipasi relatif kecil. 
Untuk mengualifikasi apakah produk hukum itu responsif atau konservatif, indikator yang dipakai adalah proses pembuatan hukum, sifat, fungsi hukum dan kemungkinan penafsiran atas sebuah produk hukum. Semakin banyak partisipasi masyarakat semakin mendekati hukum yang responsif, dan sebaliknya semakin kecil partisipasi kelompok masyarakat, semakin jauh pula hukum itu dari karakter hukum yang responsif. Maka untuk karakter produk hukum ini disebut konservatif atau ortodoks atau elitis.

\section{Relasi Politik Hukum Orde Baru dengan Kompilasi Hukum Islam}

Hubungan keterpengaruhan politik hukum Orde Baru terhadap KHI yang berada dalam tata hukum Indonesia. Dalam konteks sosiopolitik tersebut, KHI yang bersubstansi Hukum Islam itu dapat disebut sebagai produk keputusan politik.

Instrumen yang digunakan sebagai justifikasi keberlakuannya adalah Inpres Nomor 1 Tahun 1991. Selain merupakan formulasi Hukum Islam dalam tata hukum Indonesia, KHI dapat diklaim sebagai representasi dari (sebagian) substansi hukum materiil Islam yang dilegislagikan oleh penguasa politik Orde Baru.

Berdasarkan proses penyusunan KHI itu, tidak lain adalah sebuah produk hukum dari proses politik rezim Orde Baru. Oleh sebab itu, selain bersifat politically constructed, KHI dengan segala bentuknya, kecuali spiritualitas hukum Islamnya merupakan cerminan kehendak sosial para pembuatnya. Kehadirannya dengan demikian, sejalan dengan motif motif sosial, budaya dan politik tertentu dari pemberi legitimasi, dalam hal ini rezim politik Orde Baru. Sebagaimana dikatakan oleh Mahfud MD, bahwa: Perkembangan konfigurasi politik senantiasa mempengaruhi perkembangan produk hukum. Konfigurasi politik tertentu senantiasa melahirkan produk yang memiliki karakter tertentu. Konfigurasi politik yang demokratis senantiasa melahirkan hukum-hukum yang berkarakter responsif atau populistik,

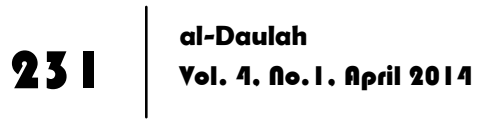


sedangkan konfigurasi politik otoriter senantiasa melahirkan hukum-hukum yang berkarakter konservatif/ortodoks/elitis. ${ }^{18}$

Dari pemaparan Moh. Mahfud MD di atas dapat disimpulkan bahwa mafhum muwafaqah KHI sebagai produk hukum dari politik rezim Orde Baru jelas mengandung berbagai karakter hukum yang sepadan dengan konfigurasi politik Orde Baru. Konfigurasi politik hukum Orde Baru akan menentukan atau mempengaruhi arah politik hukum Islam, dalam hal ini KHI. Oleh sebab itu di dalam materi KHI pasti terdapat sejumlah karakter hukum sebagai akibat pengaruh interaktif dari visi politik hukum yang sengaja dikembangkan Orde Baru.

Terlebih lagi awal kelahiran KHI, pada saat pulihnya hubungan Islam dan penguasa dari antagonistik kearah yang akomodatif. Terjadinya pergeseran sikap politik rezim Orde Baru karena umat Islammenunjukkan sikap yang akomodatif, seperti kesediaan menerima asas tunggal Pancasila. ${ }^{19}$

Melihat sejarah kemunculan KHI, proses pembentukan, keterlibatan para pihak, substansi dan instrumen hukum yang digunakan tampak sekali bahwa KHI berada dalam logika dan realitas politik hukum Orde Baru. Menurut Sutandyo bahwa perkembangan hukum nasional dalam era Orde Baru diarahkan balik ke upaya-upaya untuk memulihkan kewibawaan hukum dan menentang setiap usaha memperhamba hukum kepada kepentingan-kepentingan dan tujuan-tujuan politik. ${ }^{20}$

Pengaruh-pengaruh tersebut membawa konsekuensi untuk memperbincangkan kembali diskursus hukum agama dan hukum negara didalam wadah negara Pancasila. Dari tahun sekitar 1900 hingga 1965 umat Islam memasuki periode ideologi terutama setelah kemerdekaan dengan munculnya partai-partai Islam,

\footnotetext{
18 Moh. Mahfud MD, Hukum dan Pilar-Pilar Demokrasi, (Yogyakarta: Gama Media, 1999), 195

19 Abdul Aziz Thaba, Islam dan Negara dalam Politik Orde Baru, (Jakarta: Gema Insani Press, 1996), 279

${ }^{20}$ Sutandyo Wignjosubroto, Dari Hukum Kolonial Ke Hukum Nasional, Jakarta: Gema Insani Press, 1996), 227
} 
mendorong terjadinya transformasi Islam kedalam bentuk ideologi politik. Dalam proses ideologi itu terjadilah artikulasi dari nilainilai dasar keislaman dengan memperjelas atau membuat tuntutan doktrin lebih eksplisit. ${ }^{21}$

Sebagai hukum positif, keberadaan KHI membutuhkan legitimasi politis dan yuridis dari kekuasaan negara. Mengingat negara Indonesia adalah negara Pancasila yang telah ditetapkan sebagai cita hukum dan sumber dari segala sumber hukum, maka justifikasi itu mau tidak mau harus sesuai dengan ideologi Pancasila.

Pembentukan hukum diselenggarakan melaui proses secara terpadu dan demokratis berdasarkan Pancasila dan UUD 1945, serta menghasilkan produk hukum hingga tingkat peraturan pelaksanaannya. ${ }^{22}$

Dalam paradigma agama, Hukum Islam wajib dilaksanakan oleh setiap umat Islam secara kaffah, tidak mengenal ruang dan waktu. Pluralitas aliran mazhab merupakan rahmat dalam pelaksanaan fiqh. Keterbukaan ijtihad dan tajdid merupakan bagian dari karakter dinamis dan elastis (murunah) Hukum Islam dalam merespon perkembangan zaman. Penerapan ke dalam kehidupan sosial menjadi misi agama yang suci. Seperti disebutkan dalam firman Allah mengenai seruan untuk menegakkan hukum-hukum Allah ke dalam kehidupan nyata dan berlaku adil, yaitu QS. AlMaidah ayat 42 yang bebrunyi:

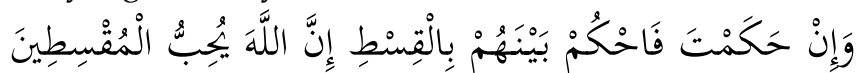

Artinya: "Dan jika kamu memutuskan perkara mereka, maka putuskanlah (perkara itu) di antara mereka dengan adil, sesungguhnya Allah menyukai orang-orang yang adil." (QS. Al-Maidah: 42) ${ }^{23}$

\footnotetext{
${ }^{21}$ Taufiq Abdullah, Islam Dan Masyarakat: Pantulan Sejarah Indonesia, (Jakarta: LP3ES, 1987), 79

${ }^{22}$ Cik Hasan Bisri, Peradilan Islam dalam Tatanan Masyarakat Indonesia, (Bandung: Remaja Rosdakarya, 1997), 19

${ }^{23}$ Depag RI, Al-Qur'an dan Terjemahannya, (Bandung: CV Penerbit Diponegoro, 2006), 166
}

\section{Vol. 4. no.I. April 2014}


Pada saat yang sama, Hukum Islam berada dalam penguasaan negara. Negara mempunyai hukumnya sendiri, yakni sistem hukum Pancasila. Politik hukum negara Orde Baru menghendaki hanya ada satu hukum nasional yang mengabdi kepada kepentingan nasional, yakni satu sistem hukum yang berdasarkan Pancasila dan UUD 1945 dan mempertimbangkan pluralitas agama, etnis, ras, dan golongan. Hukum nasional yang berintikan pada keadilan dan kepastian itu dibentuk untuk menunjang dan mendukung program-program pembangunan nasional. Abdurrahman Wahid juga berpendapat bahwa hukum agam (Islam) dimanapun berada memiliki hakikat ganda, di satu pihak dilaksanakan oleh penguasa dengan menjadi bagian hukum formal, di pihak lain ia dilaksanakan secara sukarela oleh masyarakat. ${ }^{24}$

Orientasi hukum negara mengarah pada unifikasi dan kodifikasi hukum, demi kepastian dan ketertiban. Dalam konteks pluralitas dan kompleksitas wilayah hukum Islam, legislasi hukum Islam ke dalam hukum negara membuka peluang terjadi proses reduksionisasi sampai pada tingkat yang dikehendaki oleh negara dan membuat penganut agama lain merasa tidak terancam.

Kepastian hukum dan ketertiban adalah dua hal yang menjadi tujuan politik hukum Orde Baru untuk mewujudkan keadilan hukum dalam menunjang pembangunan nasional. Upaya tersebut ditempuh dengan menciptakan dan menerapkan aturanaturan hukum melalui perundang-undangan secara ketat. KHI adalah bagian dari upaya tersebut untuk mendapatkan kepastian dan ketertiban dalam praktik yustisial dalam lingkungan Peradilan Agama.

Kenyataan-kenyataan interaksi yang simbiotik mutualistik antara hukum Islam dan politik hukum Orde baru seperti tersebut di atas terjadi dalam pembentukan KHI.

${ }^{24}$ Abdurrahman Wahid, "Menjadikan Hukum Islam Sebagai Penunjang Pembangunan" dalam Agama dan Tantangan Zaman, (Jakarta: LP3ES, 1985), 15 


\section{Karakter Hukum Kompilasi Hukum Islam}

Untuk memperjelas kerangka analisis pada aspek ini perlu diklarifikasi terlebih dahulu bahwa yang dimaksud dengan strategi pembentukan hukum adalah proses perbenturan visi dan kepentingan antar kelompok-kelompok sosial dalam proses konseptualisasi hukum, aplikasi dan institusionalisasi proses politik. ${ }^{25}$

Dalam sejarah hukum ada dua model pembangunan/pembentukan hukum sebagai hasil proses politik dalam suatu masyarakat, yaitu strategi pembangunan hukum ortodoks dan strategi pembangunan hukum responsif. ${ }^{26}$

Sebagaimana telah dijelaskan pada bab-bab sebelumnya bahwa produk hukum ortodoks apabila proses pembentukannya didominasi oleh institusi-institusi negara (pemerintah dan parlemen). Namun sebaliknya jika lembaga-lembaga peradilan dan kelompok-kelompok sosial atau individu-individu didalam masyarakat mempunyai peran besar secara partisipatif, maka strategi pembentukannya disebut responsif. Bagaimana dengan strategi pembentukan Hukum Islam dengan KHI.

Berdasarkan penelusuran sejarah kemunculan ide pembentukan KHI, tampak bahwa ide itu datangnya dari lingkaran elit politik pemegang kekuasaan politik, baik kekuasaan eksekutif maupun yudikatif melalui kerjasama antara Mahkamah Agung dengan Departemen Agama, juga melibatkan tokoh-tokoh masyarakat Islam. ${ }^{27}$

Ide dari kalangan elit politik tersebut dapat dipahami, karena problem teknis yustisial Peradilan Agama. Bagi Mahkamah Agung

\footnotetext{
${ }^{25}$ Abdul Hakim G. Nusantara, "Kebijaksanaan dan Strategi Pembangunan Hukum Di Indonesia : Sebuah Tinjauan Kritis Politik Pembinaan Hukum Nasional" dalam Artidjo Alkostar dan M. Sholeh Amin [Ed.] Pembangunan Hukum dalam Perspektif Politik Hukum Nasional, (Jakarta: Radjawali Pers, 1986), I55

${ }^{26} \mathrm{lbid}$.

${ }^{27}$ Lihat Proses Pembentukan Kompilasi Hukum Islam melalui SKB Ketua Mahkamah Agung Dan Menteri Agama RI No. 07 KMA/I 985 dan No. 25 tahun 1985, tanggal 2I Maret 1985
} 
RI selaku penanggung jawab dan pembina teknis Peradilan Agama ( pasal 5 ayat 1 UU No. 7 Tahun 1989), kelangkaan hukum materiil Islam secara positif dapat dijadikan pedoman bagi para Hakim Pengadilan Agama dalam menyelesaikan suatu perkara dibidang kewarisan, perwakafan, perkawinan, wasiat, hibah dan shadaqah. Dengan demikian, tampaknya pembentukan KHI lebih cenderung pada motif-motif yuridis dari pada politis ideologis, apalagi motif murni keagamaan.

Secara teoritis, konfigurasi politik senantiasa mempengaruhi KHI ini. Rezim Orde Baru terutama pada tahun 1962-1982 senantiasa curiga akan gerakan-gerakan umat Islam, konfigurasi politik pada periode ini, cenderung otoriter dengan berbagai model perpolitikan, seperti politik birokratis dan rezim otoriter. Meskipun di tahun 1970 lahir berbagai produk hukum, pada gelombang ini kunfigurasi politik pemerintah bersifat otoriter dan karakter produk hukum yang lahir konservatif/ortodoks/elitis.

Sedangkan pada fase berikutnya Orde Baru berangsur menjalin hubungan dengan umat Islam, maka tercipta hubungan yang reciprokal kritis (1982-1985), yakni mulai ada usaha untuk saling mengerti dan menjalin hubungan. Pada saat sikap akomodatif (1985-1998) terjadi saling pengertian antara umat Islam dan pemerintahan Orde Baru. ${ }^{28}$ Pada era inilah lahir Kompilasi Hukum Islam (KHI) di Indonesia.

Dilihat dari produk hukum yang dijadikan studi kasus dalam kajian ini, KHI dari segi pembentukan hukumnya ini dapat disebut bersifat responsif, karena materi hukum yang dikandungnya sangat aspiratif dan cenderung akomodatif terhadap umat Islam karena didalam penyusunannya banyak melibatkan para tokoh, ulama, cendekiawan Islam. KHI ini lahir dari konfigurasi politik yang demokratis karena pemerintah Orde Baru melakukan politik akomodatif terhadap umat Islam, maka karakter hukumnya bersifat responsif. Dari segi perspektif materi

${ }^{28}$ Abdul Aziz Thaba, Islam dan Negara Dalam Politik Orde Baru, 279

\begin{tabular}{l|l}
236 & $\begin{array}{l}\text { al-Daulah } \\
\text { Vol. A. no.1. April } 2014\end{array}$
\end{tabular} 
hukum, politik hukum pemerintah bersifat otonom dan responsif, produk hukum ini mencerminkan harapan masyarakat.

Perlu juga dikemukakan disini, sebagaimana pendapat Mahfud MD, bahwa kualifikasi tentang konfigurasi politik dan karakter produk hukum tidak dapat diidentifikasi secara mutlak, sebab dalam kenyataannya tidak ada satu negarapun yang sepenuhnya demokratis atau sepenuhnya otoriter. Begitu pula tidak ada satu negarapun yang memproduk hukumnya dengan karakter yang mutlak responsif atau mutlak konservatif. ${ }^{29}$

Keberhasilan legislasi KHI yang saat ini dianggap sebagai paling maksimal, tidak semata karena political will dari pemerintah, melainkan juga karena umat Islam Indonesia sesungguhnya bukan hanya bagian integral dari operasionalisasi agama saja, melainkan secara sosiologis ia telah menjadi normanorma dan etika sosial masyarakat.

Di beberapa daerah, hukum Islam melebur dengan tradisi dan kultur masyarakat setempat, bahkan hukum Islam yang dijadikan tolok ukurnya. Ini artinya, hukum Islam telah menjadi kesadaran sosial dan merupakan hukum yang hidup terus menerus di tengah-tengah masyarakat. Sebuah konsekuensi logis bila substansi hukum diberikan instrumen hukum positif, seperti KHI, sebagai suatu sikap yang aspiratif dan bukti pengakuan atas hukum yang berkembang di tengah-tengah masyarakat.

Agar karakter hukum KHI tidak konservatif, maka hakim dalam menyelesaikan perkara-perkara yang diajukan kepadanya, wajib memperhatikan dengan sungguh-sungguh nilai-nilai hukum yang hidup dalam masyarakat, sehingga putusannya sesuai dengan rasa keadilan. ${ }^{30}$ Kaidah Fiqhiyah mengatakan:

\footnotetext{
${ }^{29}$ Moh. Mahfud MD, Politik Hukum, 5

${ }^{30}$ Saekan dan Erniati Efendi, Sejarah Penyusunan, I 45
} 


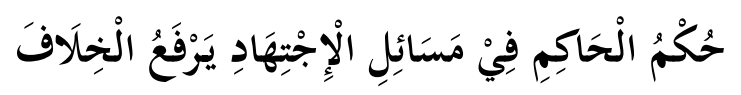

"Keputusan hakim dalam ijtihad dapat menghilangkan persengketaan." 31

\section{KHI: Fiqh Berwawasan Pancasila}

Keberadaan hukum di tengah-tengah kehidupan masyarakat apapun bentuk dan labelnya, dengan demikian dapat dikatakan tidak bebas nilai, tidak bebas kepentingan, dan tidak bebas kekuasaan. Hukum senantiasa dipenuhi dan diliputi dengan nilainilai tertentu sesuai dengan kehendak pembuatnya.

Hukum memang bukan sekedar kumpulan teks (penyataanpernyataan) semata, melainkan mempunyai tujuan, jangkauan, dan kehendak-kehendak sosial tertentu. Hukum tidak netral dan tidak pula obyektif. Hukum pada kenyataannya tunduk pada kekuasaan politik, sesuatu yang terbalik, hukum seharusnya berada di atas segalanya.

Hukum Islam dengan wujud KHI dalam tata hukum Indonesia tidak diperdebatkan lagi dan diakui sebagai hukum positif. Dalam perspektif politik hukum Orde Baru yaitu (1) Cita hukum Pancasila, (2) Wawasan hukum nasional, yaitu wawasan nusantara, wawasan kebangsaan, dan wawasan Bhineka Tunggal Ika, (3) Politik kodifikasi dan unifikasi. Tampaknya Inpres Nomor 1 Tahun 1991 adalah hukum transisi untuk menuju pada kekuatan hukumpositif tertulis seperti dalam tata aturan perundangundangan. Artinya, KHI adalah eksperimentasi politik pemerintah Orde Baru dalam memberlakukan hukum Materiil Islam.

Meskipun bentuk formal kehadiran KHI hanya didukung dalam bentuk Inpres, tidak mengurangi sifat legalitas dan otoritasnya. Segala yang dirumuskan didalamnya, benar-benar "sangat dibutuhkan" ketertiban masyarakat Islam masa kini dan masa yang akan datang. Kandungan isinya pun secara sungguh-

31 Muchlis Usman, Kaidah-Kaidah Ushuliyah dan Fiqhyah, cet. 3, Jakarta: PT Raja Grafindo Persada, 1999), 191 
sungguh telah diupayakan agar benar-benar sesuai dengan keinginan dan kesadaran masyarakat pemakainya. Bahkan ukuran, warna dan jahitannya, sudah diusahakan persis sesuai dengan kesadaran yang hidup secara aktual ditengah-tengah dinamika tuntutan perkembangan sosial, budaya, ekonomi dan teknologi. ${ }^{32}$ Namun demikian, kehadiran KHI tidak terlepas dari segala kekurangan dan kelemahannya, karena kesempurnaan yang mutlak hanya milik Allah SWT semata. Kaidah ushul Fiqh mengatakan:

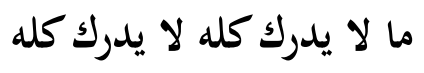

"Sesuatu yang tidak dapat dicapai secara keseluruhan, tidak dapat ditinggalkan secara keseluruhan". ${ }^{33}$

Bustanul Arifin menyebut KHI sebagai fiqh dalam bahasa undang-undang dan sebuah reformasi hukum Islam dapat dipahami. ${ }^{34}$ Akan tetapi karena kuatnya penetrasi ideologi Pancasila serta seluruh instrumennya terhadap KHI, studi ini cenderung menyebut KHI sebagai fiqh berwawasan Pancasila, suatu tipologi hukum Islam kontemporer ala Indonesia. Penyebutan ini tentu saja didasarkan pada substansi KHI yang bernilai Islam dengan berbagai akulturasi, bahasa, struktur, serta logika hukum beserta landasan formal materiilnya yang senantiasa mengacu pada nilai-nilai Pancasila seperti terlembaga dalam politik hukum nasional.

\section{Penutup}

Pada dasarnya konfigurasi politik hukum Orde Baru itu berpijak pada Pancasila dan UUD 1945 sebagai kerangka dasar kebijakannya. Sebagai penjabaran dari pedoman dasar itu adalah

\footnotetext{
32 Yahya Harahap, Kedudukan dan Kewenangan dan Acara Peradilan Agama, Jakarta: Pustaka Kartini, 1990), 29

${ }_{33}$ Muchlis Usman, Kaidah-Kaidah Ushuliyah, 175

34 Bustanul Arifin, Pelembagaan Hukum Islam di Indonesia: Akar Sejarah, Hambatan dan Prospeknya, (Jakarta: Gema Insani Pers, 1996), 53
} 
ketetapan MPR yang tercantum dalam Garis-Garis Besar Haluan Negara (GBHN). GBHN merupakan kebijakan-kebijakan pokokpokok yang akan dijadikan pemerintah dalam menjalankan tugas pemerintahannya. Dalam GBHN ini dikemukakan adanya keinginan peningkatan dan penyempurnaan hukum nasional.

Pembentukan KHI dilatarbelakangi dan didorong oleh kebutuhan teknis yustisial Peradilan Agama. Pembentukan KHI dilaksanakan oleh sebuah tim pelaksana proyek yang ditunjuk dengan Surat Keputusan Bersama ketua Mahkamah Agung dan Menteri Agama Nomor 07/KMA/1985 dan Nomor 25 tahun 1985 pada tanggal 25 Maret 1985. Salah satu fungsi penjabaran dalam konsideran SKB tersebut adalah mengadakan KHI yang selama ini menjadi hukum materiil di Pengadilan Agama.

Pengaruh politik hukum Orde Baru terhadap KHI adalah KHI dapat dikatakan sebagai fiqh Indonesia yang berwawasan Pancasila. Hal ini didasarkan pada substansi KHI yang bernilai Islam dengan berbagai akulturasi, bahasa, logika hukum beserta landasan formal materiilnya senantiasa mengacu pada nilai-nilai Pancasila yang terlembaga dalam politik hukum nasional dan mengarah pada politik kodifikasi dan unifikasi hukum.

\section{Daftar Pustaka}

Abdullah, Abdul Gani. "Pemasyarakatan Inpres No. 1/1991 Tentang Kompilasi Hukum Islam", dalam Mimbar Hukum, No. 5 Thn. III, 1992.

Abdullah, Taufiq. Islam Dan Masyarakat: Pantulan Sejarah Indonesia. Jakarta: LP3ES, 1987.

Arifin, Bustanul. Pelembagaan Hukum Islam di Indonesia: Akar

Sejarah, Hambatan dan Prospeknya. Jakarta: Gema Insani Pers, 1996.

Basyir, Ahmad Azhar. "Pemasyarakatan Kompilasi Hukum Islam Melalui Jalur Pendidikan Non Formal" dalam Mimbar Hukum, No. 5 Tahun III 1992. 
Bisri, Cik Hasan. Peradilan Islam dalam Tatanan Masyarakat Indonesia. Bandung: Remaja Rosdakarya, 1997.

Depag RI. Al-Qur'an dan Terjemahnya. Bandung: CV Penerbit Diponegoro, 2006.

Djazuli, A. "Beberapa Aspek Pengembangan Hukum Islam", dalam Juhaya S. Praja. Hukum Islam di Indonesia: Pemikiran dan Praktek. Bandung: Remaka Rosdakarya, 1994.

Halim, Abdul. Peradilan Agama Dalam Politik Hukum di Indonesia : dari Otoriter Konservatif Menuju Konfigurasi DemokratisResponsif. Jakarta: PT. RajaGrafindo Persada, 2000.

Harahap, Yahya. Kedudukan Kewenangan dan Acara Peradilan Agama. Jakarta: Pustaka Kartini, 1990.

Ichtijanto. "Pengembangan Teori Berlakunya Hukum Islam di Indonesia," dalam Juhaya S. Praja (ed.), Hukum Islam di Indonesia: Perkembangan dan Pembentukannya, Cet. I, Bandung: Remaja Rosdakarya, 1991.

MD, Moh. Mahfud. Hukum dan Pilar-Pilar Demokrasi. Yogyakarta: Gama Media, 1999.

-------. Politik Hukum di Indonesia. Jakarta: PT. Raja Grafindo Persada, 2009.

Nusantara, Abdul Hakim G. “Kebijaksanaan dan Strategi Pembangunan Hukum Di lndonesia : Sebuah Tinjauan Kritis Politik Pembinaan Hukum Nasional" dalam Artidjo Alkostar dan M. Sholeh Amin [Ed.] Pembangunan Hukum dalam Perspektif Politik Hukum Nasional. Jakarta: Radjawali Pers, 1986.

Partanto, Pius A. dan M. Dahlan Al-Barry. Kamus Ilmiyah Populer. Surabaya: Arkola, 1994

Saekan, dan Erniati Effendi. Sejarah Penyusunan Kompilasi Hukum Islam di Indonesia. cet. ke-1, Surabaya: Arkola, 1997.

Sanit, Arbi. Swadaya Politik Masyarakat: Telaah Tentang Keterikatan Organisasi Masyarakat: Partisipasi Politik Pertumbuhan Hukum Dan Hak Asasi. Jakarta: Rajawali Press, 1985. 
SKB Ketua Mahkamah Agung Dan Menteri Agama RI No. 07 KMA/1985 dan No. 25 tahun 1985, tanggal 21 Maret 1985 tentang Proses Pembentukan Kompilasi Hukum Islam

Thaba, Abdul Aziz. Islam dan Negara dalam Politik Orde Baru. Jakarta: Gema Insani Press, 1996.

Usman, Mukhlis. Kaidah-Kaidah Ushuliyah dan Fiqhiyah. cet. 3, Jakarta: PT Raja Grafindo Persada, 1999.

Wahid, Abdurrahman. "Menjadikan Hukum Islam Sebagai Penunjang Pembangunan" dalam Agama dan Tantangan Zaman. Jakarta: LP3ES, 1985.

Wahid, Marzuki. "Konfigurasi Politik Hukum Islam di Indonesia: Studi tentang Pengaruh Politik Orde Baru terhadap Kompilasi Hukum Islam", dalam Mimbar Studi, Nomor 2 Tahun XXII, Januari-April, 1999.

Wignjosubroto, Sutandyo. Dari Hukum Kolonial Ke Hukum Nasional. Jakarta: Gema Insani Press, 1996. 